\title{
Perceptions of Teachers and Subject Advisers Regarding Curriculum Development Processes in Fort Beaufort District, Eastern Cape
}

\author{
Uloma Nkpurunma Obi ${ }^{1, *} \&$ Ignatius Khan Ticha ${ }^{1}$ \\ ${ }^{1}$ Faculty of Applied Sciences, Cape Peninsula University of Technology (CPUT), South Africa \\ *Correspondence: Faculty of Applied Sciences Cape Peninsula University of Technology (CPUT), South Africa. \\ E-mail: ObiU@cput.ac.za
}

Received: July 11, 2021

Accepted: August 23, $2021 \quad$ Online Published: October 28, 2021

doi:10.5430/jct.v10n4p1

URL: https://doi.org/10.5430/jct.v10n4p1

\begin{abstract}
This study was designed to investigate the perceptions of teachers and subject advisers regarding the curriculum development processes in Fort Beaufort District in the Eastern Cape, South Africa. The sample consisted of twenty-two respondents: four principals, twelve teachers and six subject advisers. Data were collected through structured face-to-face interviews, focus group discussions and document analysis. The findings revealed that both teachers and subject advisers were concerned about the quality of teachers and learners as well as delivery of the curriculum. They also expressed concern about the quality of workshops; pointing to how much participation from teachers and subject advisers occurs in these workshops. Their responses create space for the researcher to engage with the question, does their involvement in these workshops help them to understand the curriculum and implement it better? Hence, this study recommends that the quality of teachers, learners and subject advisers should be considered while carrying out curriculum development processes.
\end{abstract}

Keywords: curriculum development, stakeholders, participation, involvement, and voice

\section{Introduction}

A series of curriculum reforms were instituted by the democratic government after the Apartheid regime (Chisholm, 2005 and Bantwini, 2009). These curriculum reforms were met with a lot of criticism and the government felt they were not serving their purpose. Some key stakeholders felt that their non-involvement, non-participation, and the lack of proper consultation in the curriculum process were partly responsible for teachers and subject advisers misinterpreting the curriculum and implementing it improperly. The issue of participation cannot be overemphasized because, participation is also specified in policies like the South African Schools Act (SASA) which states that all schools must be democratically governed, or managed. Similarly, the White Paper on Education emphasizes full participation by stakeholders in the process of curriculum development (National Department of Education, 1995; The White Paper on Education and Training, 1994; South African School's Act No. 84 of 1996).

In the first decade of the democratic government, a review was done and the National Curriculum Statement (NCS) was launched in 2002. However, the criticisms and complaints persist, probably due to continuing poor performance at the Matric Examination which continues to feature low pass rates for many provinces, especially the Eastern Cape. Against this backdrop, the government streamlined the curriculum, amending the NCS to the Curriculum and Assessment Policy Statement (CAPS) which emerged in 2012 (Taole, 2013). The frequent curriculum reviews and the processes followed resulted in different views and perceptions especially among teachers and subject advisers.

A key issue raised by critics is the lack of sufficient involvement of stakeholders in the curriculum review processes. This was based on the view that consulted stakeholders were mainly representatives at the national level and teachers at the local levels felt left out, uninformed and unprepared (Jansen, 1998a, 1998b). Additionally, a view was held that Teachers' Unions and schools were not actively involved. Besides the concern around the non-involvement of all stakeholders, concerns were raised that teachers were not using the curriculum properly, many of them were under-qualified, the teacher/pupil ratios were still above 60 and all these resulted in very poor performance by the learners. On its part, the government maintained that it engaged in adequate consultations with all relevant 
stakeholders. There are obvious differences of interpretation on stakeholder involvement and participation and there is urgent need to reconcile whatever differences of opinion that exist, in order to gain common understanding, which is the first step in reaching a solution.

\section{Aim of the Study}

The aim of this study was to determine the extent to which teachers and subject advisers were involved in curriculum development in South Africa, especially in the Fort Beaufort District in the Eastern Cape. Also, to explore their perceptions both of the process followed as well as of their participation in curriculum development.

\section{The Main Research Question}

The main research question that guided this study is:

- How do teachers and subject advisers perceive both the process followed, as well as their participation in curriculum development in the Fort Beaufort District in the Eastern Cape Province?

\section{Sub-questions:}

- To what extent are teachers and subject advisers involved in curriculum development?

- How do teachers and subject advisers perceive the process followed as well as their participation in curriculum development?

- How are teachers and subject advisers involved in the process of curriculum development?

- Which categories of teachers and subject advisers are involved in curriculum development?

\section{Theoretical Framework}

Curriculum development is a continuous process which aims to guide all learning within a given programme of education or training (Taylor, 2000). Curriculum development is more likely to be effective if it is undertaken using the participatory approach (Taylor, 2000). Participation could be defined as "a process where individuals, groups and organisations choose to take an active role in making decisions that affect them" (Wandersman, 1981; Wilcox, 2003; and Rowe et al, 2004). Participatory curriculum development 'involves a wide range of stakeholders in a meaningful way, drawing upon their experiences and insights in a structured approach to curriculum planning, implementation and evaluation' (Taylor, 2000). Hence, a participatory curriculum development approach aims at developing a curriculum from interchanges of experience and information between the various stakeholders. This study will examine how teachers and subject advisers perceive the extent of their participation and involvement in the curriculum development process in South Africa, especially in the Eastern Cape. It will also engage with teachers' perceptions of the type of help given to them by subject specialists in the implementation of the curriculum.

The participatory approach can take different forms and levels. These include: (1) Information Sharing which involves dissemination of materials to the local population through public meetings. (2) Consultations which involve field visits (Long, 2001; Nelson \& Wright, 1995). (3) Joint Assessment Mechanism, which involves beneficiary assessments through surveys or interviews. (4) Shared Decision-Making Assessments which involve workshops that help groups come to joint decisions. (5) Collaborative Mechanism which involves joint working groups that hand over primary responsibility for implementation to stakeholders. (6) Most participatory approaches are empowerment mechanisms. These involve capacity building, project management delegation and support for new spontaneous initiatives by stakeholder organizations (World Bank, 1994, cited in Long, 2001). In the South African context currently under study the perceptions of teachers and subject advisers on the extent of their participation and involvement in curriculum development would be examined

\section{Methodology}

\subsection{Research Design}

The study was a case study located within the interpretive paradigm. It used a qualitative research design to collect data, with the primary intent of developing themes from the data (Creswell, 2014). The study would analyse the narrative provided by the respondent, enanging with words that help in the understanding of the phenomenon as 
explained by Schumacher and McMillan, (2001)

\subsection{Population and Sample}

Fort Beaufort District has a total of forty-seven secondary schools distributed across six clusters. The population includes teachers, subject advisers, and principals.

\subsection{Site Selection}

The site selection was done purposively. There are six clusters and the four schools selected came from these six clusters. The sample consists of 4 teachers, 6 subject advisers, and 4 principals that were purposively selected from 6 high schools across 4 clusters in the Fort Beaufort District. Additionally, the sample comprises of two secondary schools (one rural and one urban). One of the schools is an ex-model C school and the other a boarding school, all in Fort Beaufort District. This is to ensure that a variety of management and administrative approaches adopted by the different schools, as well as experiences in the different schools enrich the study. The principals who acted as gatekeepers to the process of recommending participants were trusted to select teachers who will give accurate and reliable information. The sample selected was suitable for achieving this purpose (of accessing accurate and reliable information) based on certain characteristics like the position of the respondents, experience, and relevant knowledge of the topic under study.

\subsection{Data Collection}

The data were collected through face-to-face interviews, focus group discussions and document analysis. The researcher held fourteen face-to-face interviews with teachers and principals from four high schools in the district and six subject advisers from the district office. They also conducted two focus group discussions with teachers from two high schools: one ex-model C school and one boarding school, both in Fort Beaufort District. This selection is to get views of teachers who are in former Model C School, and had more privileges and opportunities to have participated in the curriculum review process and also from teachers who are in a rural area who might not have been contacted to participate in the curriculum review process. The sample represented four out of the six clusters in the district.

\subsection{Data Analysis}

Qualitative data was analysed by clustering common themes and highlighting the main issues that arose. These issues were then put together as findings of the study.

\subsection{Ethical Considerations}

According to Waters-Adams (2006), any research which involves human in some way has ethical implications. Gathering and analysing data within this study inevitably impacted on the lives of other people in this study. Hence it was proper that the researcher adhered to the ethical considerations as stipulated in the University of Fort Hare Guidelines for Post Graduate Qualification Policies and Procedures so as to ensure that individual rights were not infringed upon and to make sure that the data were interpreted correctly.

Alongside this, principles such as getting informed consent, respecting the rights to privacy and participation, anonymity, confidentiality, avoiding harm to participants and other principles highlighted by Babbie (2007) were adhered to during the data collection process, data analysis and interpretation.

\section{Findings and Discussion}

In the course of this study, it was important that the participants express their perceptions concerning participation in the curriculum development process that took place in the Fort Beaufort district in the Eastern Cape Province. With the use of interviews and focus group discussions, the participants were able to express their concerns pertaining to the areas and stages they should have participated during the curriculum development process that took place. They also expressed their perceptions on the levels at which they should participate in curriculum development as well as on the process used to contact them.

\subsection{Participants' Perceptions on the Curriculum Development Process}

The teachers, subject advisers and principals were asked how they viewed their participation in the curriculum development that took place and they made the following comments:

T2: we get the instruction and we have to implement it. If we could have input during the designing, that will be right. 
T3: Teachers should be involved in the designing of the curriculum especially those who have the expertise.

T4: The curriculum should not be handed down to teachers to implement. Emphasis should be put on teachers getting involved in designing and giving their inputs.

On the issue of the process followed in the curriculum development that took place, the teachers interviewed expressed their displeasure at the idea of the curriculum being handed down to them to implement. They felt that the top-down approach was wrong. This is a view that Carl, (2005) shared that top-down approach is non participatory process. Hence, T1 made mention of teachers not being able to understand the curriculum, and the language and vocabulary being complicated. All other teachers emphasised the importance of teachers being involved in the designing of the curriculum.

The subject advisers were also asked the same questions on the same issue, and their views were captured in the following responses:

SA1: It is more of a National issue that involves the subject advisers. The CESs and DCESs are the ones that are closer to the National level. The government might be doing a good thing but how they are doing it is the problem. For instance, introducing tablets in schools when some of them do not have access to cell phones, they could have asked the subject advisers first. The subject advisers know these schools, the teachers and the learners well. The level at which they are using it end up distorting the whole thing.

SA1 commented that the government might have been doing something good but the way they were going about it was wrong. He said that the government needed to work with Chief Education Specialists (CESs) and Deputy Chief Education Specialists (DCESs) more. Other subject advisers also gave their impressions concerning the curriculum development process. This points to the fact that the best curriculum development approach may end up as a failure if it is not aligned to the reality on the ground and if those closest to this reality (subject advisers in this case) are not made part of the process.

According to SA2:

The process did not accommodate the educators. It was only the subject advisers and cluster leaders who were actually invited to join in the curriculum committees. Many schools are supposed to be involved in the pilot programme for any curriculum development, but they used only the ones in Gauteng. They used a top-down approach to develop these curricula. Directions/Invitations came from national office or they requested for limited number of persons and others were left. If they had allowed the district to choose and decide, this would have been better. I feel that subject advisers should participate on all levels in all the stages. The subject advisers know the materials and condition on the ground. They can advise on the schools that could be used for piloting.

SA3: A lot has been done both national and provincial levels. There is still gap in implementation. Curriculum is well and good but implementation should be strengthened. There was not enough collaboration and consultation and there was limited number of subject advisers who were involved.

SA2 and SA3 commented on the participation of educators and the implementation of the curriculum respectively. SA2 feels that the government should have accommodated the teachers and ensured that they participate while SA3 commented that there is a problem with the implementation which might be because teachers were not involved in the designing. S/he added that there was not enough collaboration and consultation. SA2 also expressed displeasure in the top-down approach and advised that subject advisers should be involved in all the stages and at all the levels of curriculum development. Different authors like Pretty, Guijt, Thompson and Scoones, 1995; Chambers, 1997; Hagmann, 1999 support this view and are of the opinion that participatory processes lead to increased effectiveness in planning, implementation and evaluation of programmes.

In addition to what the other subject advisers said, SA6 stated that there is great improvement in CAPS probably because more personnel were involved.

SA6: Subject Advisers did not participate well during these developments but there were enough personnel during the formulation of CAPS. There were some developments. Teachers are appreciating the system of CAPS. In general I like the process followed in introducing CAPS; more curriculum personnel who were hands on were involved. There are some developments.

This serves as a clear indication that, some level of participation by teachers (though not to the extent that respondents expected) resulted in a more acceptable curriculum development process and by extension, a more acceptable curriculum. 
Shedding more light on the curriculum development process, the focus groups pointed out a lot of irregularities in the process that was adopted during the curriculum reforms. FG1 pointed out the fact that teachers needed to be part of the committee that designed the content as well as the assessment. Most respondents suggested that schools should always invite subject advisers to help and where possible, demonstrate teaching in the class. They revealed that some teachers and schools were very good with the old curriculum (Outcome Based Education (OBE)) and could have been allowed to make a smooth and gradual transition to the new curriculum instead of moving all schools suddenly. They anticipated that, some learners were likely to fail due to the abrupt shift to CAPS. FG1 made the following comments:

FG1: Teachers should be the designers of the curriculum. We should design assessments too. We need to do away with the common assessments we have and design assessments according to the type of learners we have in our schools. Also in designing the curriculum they need to look at the resources they have to know what to put in the curriculum.

The respondent in this case makes an appeal for the curriculum design process and the implementation of the curriculum to be guided by the specific context of the learners, the schools and the resources at the disposal of the different schools.

\subsection{Participants' Perception of Their Participation in Curriculum Development}

The researcher asked the participants their perception with regards to their participation in curriculum development and this is what the teachers had to say:

T1: If teachers go for marking that is a development and they relay that to students. It enables one to be a better teacher and explain to learners how to answer questions and that can also be relayed to other colleagues. Teachers should be involved in designing, and they should rotate to know what is going on.

T2: In the latest curriculum, there is evidence of teachers' involvement; it is now more teacher and learner friendly. But previously I don't think teachers participated in curriculum development.

T3: I think teachers' participation in curriculum development is good, at least they won't feel left out. Teachers can form associations or subject committees and they exchange visits with their colleagues' schools to help out.

T4: Because teachers did not participate, many students have been made to suffer for a curriculum that is not working.

Data elicited from the teachers indicated that they would like to participate in curriculum development from the designing stage. They highlighted the need to take part and then relay the information gathered to the learners and other colleagues. One of the teachers expressed the view that the existing curriculum was teacher-friendly because teachers had made contributions to its design. Another teacher felt that teachers' participation in curriculum development was necessary, in the sense that they would not feel left out. They relate to the curriculum very well and claim ownership of it. This is a view Carl, (2005) shares too that the discourse level on which teachers were involved in during the curriculum change, could bring about increased ownership of the curriculum and more effective curriculum development. If are not involved in the curriculum development and subsequently do not own the curriculum, they give the learners half-baked information thereby making them to suffer the consequences. One of the teachers pointed out that teachers not participating in curriculum development put the learners at a disadvantage. He explained that when unfamiliar topics are included in the curriculum, teachers skip them. They only teach things they know or are familiar with. Also, there are certain inclusions in the curriculum which may harm the environment, so teachers do not teach them. If teachers who know and understand these learners and the environment are involved in curriculum development, they will make sure that their learners and the environment are considered during the designing of the curriculum.

The study also sought to find out the subject advisers' views regarding the curriculum development process that took place as well as the role they (subject advisers) played. The following are their views:

SA1: As a subject adviser I played a key role. I cover about 260 schools. For my counterpart at National plans with 81 Districts, how can he come down to plan for 260 schools? The DCESs need to get closer to them. We are seen as agents of change.

SA4: My role was pivotal. The subject advisers serve as links between the province and the schools. Without the District it will be very difficult for the schools to work with the Province.

The data collected from the subject advisers revealed that they were very proud of the role they played in the curriculum development process. They saw themselves as agents of change in that they took the changes made to the 
schools and they also served as a link between the Province and the schools.

\subsection{Participants' Perceptions of the Areas/stages They should Have Participated in during Curriculum Development}

Although the teachers and subject advisers have explained the areas they participated in during the curriculum developments process, the researcher sought their perceptions on the areas and stages they thought they should have participated in. The teachers and subject advisers made the following suggestions:

T3: Teachers should be involved in the designing as experts. Most teachers in many schools try to improve themselves by furthering their studies. They understand their environment more. They should also be involved in implementations and evaluation. A teacher should have authority and also the least of the authority. There should be inspectors and supervisors working with them.

This teacher's response represents the opinion of the other teachers' respondents in this study They all held the opinion that teachers should be involved from the beginning; that is, from the designing stage to evaluation. They felt that teachers understand the learner and the school environment better than anyone else and that they are equipped with the skills needed to participate in all the stages - development, implementation and evaluation.

The subject advisers also felt the same way as the teachers. They felt that as curriculum implementers who work directly with the teachers and the schools, they should be involved from the beginning to the end. One of the subject advisers stated that:

SA1: They should be involved from the onset. They should participate during the designing stage; that is during policy development and this has two stages: (a) political influence: at this stage what the government wants to achieve through education is discussed. (b) The core business: at this stage, the content, how to implement it, assessment and evaluation are decided so it is important that the subject advisers are involved here. They need to understand the National Development Plan (NDP).

This subject adviser made it clear that they should be involved in curriculum development right from the designing stage through to evaluation. In his view, they should have been part of the committee that formed policies in education as well as part of the committee that designed the curriculum, implements, edits and evaluates it.

During the interview, the principals also gave their opinion on the stage in curriculum development where principals should come in. This is what they said:

P1: They should be involved in all stages.

P2: I think they should be involved in the different stages because principals need to know and make input in the curriculum.

The principals interviewed further indicated that they should have been involved from the planning stage to the evaluation. They needed to know what the curriculum was about, the content, implementation and the evaluation, considering the fact that they are curriculum managers in their various schools. They need to be part of it and make an input.

\subsection{Participants' Perceptions on the Levels at Which They should Participate in Curriculum Development}

The participants expressed their views on the levels where they should have participated during the curriculum development process. The participating teachers made the following comments:

T3: At all the levels. Personally, I think that if they participate at all levels, the learners and environment will be considered while designing the curriculum.

T2: Teachers should participate on all the levels; from cluster to district to Province then National representations.

The teachers felt that they should have participated at all the levels. They should have started from cluster and get up to the National level.

The researchers wanted to establish the level where teachers usually participate and at what level they would like to participate in subsequent curriculum development endeavours. The focus groups said: "we usually attend workshops at the District level." The researchers asked them till what level they would like to have participated and they said: "if possible, up to National level."

The subject advisers equally thought that they should have participated at all levels. They held the view that, starting from the National level where the policy is decided would enable them to make useful contributions towards the educational policy to be implemented in the country. This was how one of the subject advisers put it: 
SA1: We need to participate at the National level, during policy development then to Provincial and District.

The researchers sought to know from the participant subject advisers whether they felt that all the categories of subject advisers should go up to the national level. These were their responses:

SA1: It depends. The CESs go up to National level, the DCESs get to Provincial; some DCESs get to National. The SESs operate mainly at the District level because they deal mainly with teachers and what is happening in the classroom. If you are dealing with 'smal'l subjects like technical subjects, you may get to National because the subject advisers are quite few.

SA5: The designing was handled by top management. Implementation was mainly done at the district level by SESs and the evaluation with educators at the district level too. Also, at the National level, there are representatives of provincial planners.

These two subject advisers reiterated what they had said earlier that the level of participation depended on the category of the subject adviser. The Chief Education Specialists participate up to the national level. Some Deputy Chief Education Specialists can get to national level if they are handling small subjects (subjects that are not core). These officers occupy higher and senior positions. The Subject Education Specialists work with schools, so they mainly participate at the district level.

During the interview, the principals expressed their views concerning the level where they should have participated during curriculum development process.

P2: They should be involved at all levels. Although it doesn't have to be all the principals, there should be a representation.

It came out that the principals would also want to participate up to National level during curriculum development. They expressed the wish to be part of the committee designing the curriculum content and its implementation. In their view, the principals should be represented and necessarily all participate.

The focus groups also shared the same view that they would appreciate it if teachers were invited to participate at all levels.

\subsection{Participants' Perceptions on the Process Used to Contact Them}

Participants were requested to discuss how they were contacted to participate in curriculum development. The researcher asked the teachers, subject advisers and principals the process followed in contacting them. The following responses were provided by teachers who participated in the study:

\section{T1: There are circulars given to schools. Schools are contacted through the district office.}

T2: Circulars are sent to the principal and the principal will release the teachers to attend.

From the teachers' responses, circulars were sent to them from the District office through the principals. The principals then released them to attend the workshops.

The subject advisers explained how they were contacted to participate in curriculum development.

SA3: We are contacted telephonically, fax or e-mail. Fax is sent from the provincial office to district office.

SA2: Circulars are sent from the national government to the curriculum planner at the head office then to the district.

The subject advisers also received circulars from the national or provincial office, and this can be through telephone, fax or e-mail.

The principals also explained how they were contacted to participate in curriculum development. They said that:

P1: There are provincial people who were nominated, and they were the ones involved in the writing of the syllabus. They were the people who set the exam papers and also do the moderation. The senior teachers were used as well as the subject advisers.

P2: The District sends circulars to schools to invite them to workshops. In C2005, NCS and CAPS, there were orientations organised by the district office.

The principals were contacted in the same way that the teachers and subject advisers were contacted. They received circulars from either the District or the Province.

The focus groups pointed to the same communication process.: 
FG1: If it is at the District, they contact the principal who will then contact the teacher. But if it is at the Provincial level, the subject adviser will contact the teacher to find out if he/she is interested.

FG2: The teachers receive letters from the District through the principal

All the participants highlighted the fact that circulars were sent from the district office to the principals for District workshops. For Provincial ones, the circulars were sent from the Provincial office. Based on the responses provided, the communication channels used to invite participants to curriculum development workshops are standard and consistent and respondents seem to find it adequate and proper.

Having asked the respondents how they were contacted and invited to participate in curriculum development, it was also necessary for the researchers to find out who made the decisions regarding workshop participants. The following were comments from teachers' respondents.

T1: They take teachers who teach that particular subject usually per grade so for instance if a teacher teaching grade 10 is needed that particular teacher will go.

T2: I'm not so sure when it comes to circulars. But the principal chooses teachers from different departments, to make sure all teachers in the school get the feedback from the workshops. This is done at the district level. All the teachers get exposed to the information given at the workshops because all the subjects in the school were represented.

T4: The subject adviser puts all teaching mechanical, technical subjects together and all those teaching electrical subjects together. He groups us. If there is any teacher struggling he asks us to help.

From the teachers' explanations, when the circulars arrived at the school, the principal decided on who would attend the workshops based on the teaching subjects. The principal made sure that each subject has a representative in the workshop. One of the teachers, T4 said the subject adviser was the one who put them in groups and sent the list to the principal to decide.

Data were also collected from the subject advisers regarding the decision on who participates in curriculum development. SA2 explained:

Usually they want all the districts to be represented. But Eastern Cape is the only province with 23 districts. Others are 5 or 6, for example in the Western cape there are only three. But in Eastern Cape there are many districts so at times it becomes a problem

The response presented above highlights the unique situation of the Eastern Cape with more districts than other provinces. This should make complex (as indicated by SA2 above) the process of deciding on who to and who not to invite. However the process outlined by SA1 below should serve as a solution to the problem. He explained:

SA1: Subject planners make the recommendations, then from the planners to managers. The Council of Ministers (CMCs) takes decision(s) on the recommendation(s) made.

From the above explanation, the subject planners made the recommendation and passed it on to the Council of Ministers who then decided on who would participate. Considering that the Eastern Cape has many districts, they could not send all the subject advisers and so, a streamlined process such as that highlighted should ensure that there is no animosity.

\subsection{Participants' Perceptions of the Preparations Made before Participation}

Adequate preparations need to be made before the participants are involved in the curriculum development process. In the first place, they have to be stakeholders in education. The department needs to make sure that the curriculum personnel are well equipped and qualified to handle the process. Additionally, the timing for activities like training/workshops to take place need to be considered. Adequate preparations will ensure maximum performance and better outcomes.

The researcher needed to know if the teachers and subject advisers were prepared before they went to the workshops. The teachers responded:

T1: No, we were just given a notice that informs us that on this day so and so will take place and we are expected to be there and with our exercise books.

T2: No, they only ask you to bring certain documents; unless they need something from you then they ask you to bring them. Most often they stand and read the documents. No proper training taking place.

The above responses indicate that there were no proper preparations made before the teachers went to the workshops. 
From their responses, they were only sent a notification of the day the workshop or meeting would take place.

The subject advisers were also asked whether they were prepared before they attended the meetings and workshops and their responses were:

SA2: Yes, they give us templates to fill new content gaps because there will be a new convention on workshops. They ask us to research on the templates.

SA3: Preparations are made. Communications are made. They communicate in good time to provide ample time.

The situation seems to be quite different from that of the teachers. The subject advisers, unlike the teachers received the circulars and had enough time to prepare for the meetings and workshops.

Data from FG1 revealed that it depended on where the workshop was taking place. They explained that:

FG1: Apart from the one that took place at National level and we were told all the things to bring, others were not; but if we are going to facilitate the subject adviser sits with us in the workshop and be telling us what to do.

The above explanation shows that when it was at the National level, better preparations were made. The participants are told what to bring to the workshop and the role they would play, unlike for District workshops where they only sent letters. It was only on arrival that they were told what to do. Here, there is again a difference on what preparation happens but this time, the difference is between curriculum development events at the national level (with better preparation) versus those at lower levels (with insufficient preparation).

\subsection{Participants' Perceptions of the Frequent Curriculum Changes that Have Taken Place}

In the cause of the interview, the researchers asked the respondents to give their impression on the frequency at which the curriculum has changed. The teachers said:

T1: Changes are for us to follow or to be there. Trial and error is okay, as we try one thing to see if it will help the learners perform better; but if it will improve the performance of the learners, the performance of the district or province? I don't know.

In line with what T1 said, T2 and T3 added:

T2: If it changes for the better, I don't have any problem with that. For instance, I don't mind all these changes that we have been through because it seems now that they are getting it right. We are in a better place now. Apart from the inconveniences we face like new mind set, cost in changing books etc.

T3: At times these changes are frustrating. If the government is so sure of what it wants to do, there is no problem. If a major change is going to be done and the government is so sure of what it wants to achieve that is good, but they are not always sure of what they want to achieve.

T4 reiterates what he said earlier that:

T4: As I said earlier, the learners are the ones suffering from it more.

Data collected from the teachers revealed the views and impressions of respondents on the frequent curriculum changes that have taken place. To a majority of respondents, there was no problem with the government embarking on any change as long as the changes are beneficial. Rather, they felt that government should be quite sure of what they want to achieve and go for that. It also came out from a few respondents that such changes brought a confusion to the teachers and the learners were the ones who suffered most.

\section{Conclusion}

The participants claim that there were no active stakeholders' participation in the curriculum development process that took place. However, it was evident that there were various strategies used to get the participants to participate. During the designing stage, the teachers were engaged in workshops and some were trained by experts to train their colleagues in different subject areas. Although they did not participate directly in the designing stage, some of the teachers were cascading information to other teachers. They were used as agents to spread the news of the new curriculum. This is in order, as it falls under the eighth step on Taylor's Key Stages of PCD which reads: "implement new curricular with groups of students/trainees, evaluate and adapt curricula as required (Taylor, 2003). Significant here is the fact that a curriculum development process would not have an impact only on those directly involved and would not be impacted upon only by those who are directly involved, if the appropriate cascading systems is 
implemented to reach those not directly involved.

Unlike the teachers who could not go beyond the district level, one of the subject advisers went up to provincial and national level for training and facilitation of workshops. This could be as a result of his subject area or position. He was a Deputy Chief Education Specialist (DCES) who specialised in Mathematics and Motor Mechanics. Hence, this study can draw the conclusion that the participants' participation in the curriculum development process depended so much on their position, seniority, experience, and expertise. This brings to the fore the major problem of a top-down approach to curriculum development that results in little buy-in from those on the ground.

During the implementation stage, the teachers were occupied in the classroom at the school level as well as attending workshops at the district. On their part, the subject advisers operated at the district level where they organised workshops. There is nothing wrong with that as indicated by Wilcox (1994). Different levels are appropriate for different circumstances and so participation in curriculum development should depend on the context and setting. In line with what various scholars have indicated the findings showed that the principals participated at a very low level. They did not get to participate at District and National levels. This could imply that principals considered their roles to be mainly management of administrative matters. They indicated that they would have loved to participate in planning/designing but they were involved mainly in the evaluation. They participated indirectly by giving comments in workshops and assessments. They mainly operated in the school and had very little control over what took place in the curriculum development process beyond the school. They expressed their wish to participate in the committee that designs the curriculum content and the implementation plan at the national level. For a programme of curriculum development and revision to be successful it is important to assign responsibilities at the appropriate levels with sufficient scope and authority to implement them and deliver results.

The findings of the study indicated that the teachers were contacted through the principals to attend workshops in the Districts. The circulars are usually received late, at times on the day of the workshop. They are not given enough notice and consequently, there is no prior training, arrangements and preparation for the workshops. This affects the way the teachers take these workshops as well as the contribution they make to the process. The idea that preparation and training has to be given to teachers is in line with the view expressed by Carl (2012) and Fullan (2007) that, during curriculum innovation and implementation, it is paramount that teachers have continuous capacity building programmes to improve their professional development. However, the findings revealed that that to a certain extent the workshops organised by the subject advisers were not helpful. This was mainly because, while subject advisers are meant to help teachers decode the meaning of the curriculum the subject advisers were only reading the documents to them which they detested. Reed (2008), in the review of the related literature, also supports these findings and states that stakeholder participations through training needs to be underpinned by a philosophy that emphasises empowerment, trust and learning. Unfortunately, this appears not to be the case in the case under study.

\section{Recommendation}

In the light of these findings, it is recommended that in subsequent curriculum developments programmes, proper procedures should be followed when embarking on a curriculum development process. Even if all the stages in the Participatory Curriculum Development (PCD) process (Taylor 2003) are not followed, the government should make sure that all the important stages are carried out and done meaningfully. This is very important because, if for instance, a new curriculum is introduced without the first stage in Taylor's model, then the participants will be lost from the beginning. They should be made aware of the change in curriculum and the reason for the change. This is also consistent with Arnstein's model which advocates that the participants be involved. In that way, it will be difficult for the participants to say that they did not know anything about the change.

In relation to the levels of participation, the stakeholders' participation in curriculum development should be attended to. Although all the stakeholders cannot be there, there should be representativeness in the curriculum committees, representing different subjects, different grades, and different needs.

The workshops organised at the district level should be made more interesting, educational and interactive. Also, the organisers or facilitators should prepare very well so that the participants will benefit from them. Sufficient notice period should be given as well so that the participants can prepare well.

\section{References}

Arnstein, S. R. (1969). A Ladder of Citizen Participation. Journal of American Institute of Planners, 35(4), $216-224$. 
https://doi.org/10.1080/01944366908977225

Babbie, E. (2007). The practice of social research (international student edition). Thomson Higher Education, 10 Davis Drive, Belmont, CA 94002- 3098, USA.

Bantwini, D. B. (2009). District professional development models as a way to Introduce primary school teachers to natural science curriculum reforms in one district in South Africa. Journal of Education for Teaching, 35(2), 169-182. https://doi.org/10.1080/02607470902771094

Carl, A. (2005). The" voice of the teacher" in curriculum development: a voice crying in the wilderness? South African journal of education, 25(4), 223-228.

Carl, A. E. (2012). Teacher empowerment through curriculum development: theory into practice. Cape Town. Juta and Company Ltd.

Chambers, R. (1997). Whose reality counts? London: Intermediate Technology Publications. https://doi.org/10.3362/9781780440453.000

Chisholm, L. (2005). The politics of curriculum review and revision in South Africa in regional context. Human Science Research Council of South Africa, 35(1), 79-100. https://doi.org/10.1080/03057920500033563

Creswell, J. W. (2014). Research design: Quantitative and mixed methods approaches (4th ed.). Sage Publications Inc.

Fullan, M. (2007). The new meaning of educational change (4th ed.). New York Teachers College Press

Hagmann, J., Chuma, E., Murwira, K., \& Connolly, M. (1999). Putting process into practice: Operationalising participatory extension. ODI Agricultural Research and Extensio. Network Paper No. 94, July 1999.

Jansen, J. D. (1998). Curriculum reform in South Africa: A critical analysis of outcomes-based education. Cambridge Journal of Education, 28(3), 321-331. https://doi.org/10.1080/0305764980280305

Long, C. M. (2001). Participation of the Poor in Development Initiatives: Taking Their Rightful Place. London, England: Earthscan Publications.

Nelson, N., \& Wright, S. (1995). Participation and power. In N. Nelson, \& S. Wright (Eds.), Power and Participatory Development: Theory and Practice. Intermediate Technology Publications, London. https://doi.org/10.3362/9781780445649

Pretty, J., Guijt, I., Thompson, J., \& Scoones, I. (1995). Participatory learning and action. A trainer's guide. London, International Institute for Environment, and Development.

Reed, M. S. (2008). Stakeholder Participation for Environmental Management: A Literature Review. Biol. Conserv., 141, 2417-2431. https://doi.org/10.1016/j.biocon.2008.07.014

Rowe, G., Marsh, R., \& Frewer, L. J. (2004). Evaluation of a deliberative conference in Science. Technology and Human Values, 29, 88-121. https://doi.org/10.1177/0162243903259194

Taole, M. J. (2013). Teachers' conceptions of the curriculum review process. International Journal of Education Science, 5(1), 39-46. https://doi.org/10.1080/09751122.2013.11890059

Taylor, P. (2000a). New perspectives, new curricular. A case study of participatory curriculum development in forestry education in Vietnam (paper presented at the workshop on changing learning and education in forestry $\mathrm{Sa} \mathrm{Pa}$.

Taylor, P. (2003). How to design a training course- A guide to participatory curriculum development. London: VSO/Continuum Vietnam, April 16-19, 2000.

Waters-Adams, S. (2006). The relationship between understanding of the nature of science and practice: The influence of teachers' beliefs about education, teaching and learning. International Journal of Science Education, 28(8), 919-944. https://doi.org/10.1080/09500690500498351

Wilcox, D. (1994). Community participation and empowerment: Putting theory in practice. Brighton, UK, Partnership books.

Wilcox, D. (2003). The guide to effective participation (online). Retrieved from http://www.partnerships.org.uk/guide 


\section{Copyrights}

Copyright for this article is retained by the author(s), with first publication rights granted to the journal.

This is an open-access article distributed under the terms and conditions of the Creative Commons Attribution license (http://creativecommons.org/licenses/by/4.0/). 